\title{
Gambaran Profil Hematologi Dalam 24 Jam Pertama pada Pasien Sepsis di Unit Neonatus RSUD Dr. Pirngadi Medan Tahun 2017-2018
}

\author{
Alpa Exaudi Siahaan ${ }^{1}$, Johan Christian Silaen ${ }^{2}$, Leo J.Simanjuntak ${ }^{3}$ \\ ${ }^{1}$ Mahasiswa Fakultas Kedokteran Universitas HKBP Nommensen \\ ${ }^{2}$ Departemen IImu Kesehatan Anak Fakultas Kedokteran Universitas HKBP Nommensen \\ ${ }^{3}$ Departemen Obstetri dan Ginekologi Fakultas Kedokteran Universitas HKBP Nommensen \\ Korespondensi: Alpa Exaudi Siahaan, Email: alpaexaudisiahaan@gmail.com
}

\begin{abstract}
Background: Neonatal sepsis is a clinical syndrome on infants aged 28 days or more. According to WHO data on 19th April 2018, estimated 3 million newborns and 1.2 million children suffer from sepsis globally every year. Hematological profile assessment can be used as a clinical guide to diagnose sepsis and early management of patients with early onset, especially in hospitals with limited facilities and the examination data can be obtained faster.
\end{abstract}

Objective: This study was aimed to determine the hematological profile in sepsis patients in neonatal unit at RSUD Dr. Pirngadi Medan.

Methods: This research was a descriptive cross-sectional design. The research sample was selected by total sampling.

Results: The results of the study were found from 74 neonates, $44(59.5 \%)$ were male. Neonates with normal labor were $57(78.1 \%)$ and survived $45(60.8 \%)$. It was found that leukocytes $(76.4 \%)$, neutrophils $(60 \%)$, monocytes $(87.9 \%)$, and hemoglobin (40.3\%) were increased.

Conclusion: The hematological profile can be used as a clinical assessment of sepsis at the first 24 hours on neonates. Hematological examination found an increased leukocytes, neutrophils, monocytes, and hemoglobin in neonatal sepsis patients at the first 24 hours.

Keywords: Sepsis, Neonates, Hematological Profile

\begin{abstract}
Abstrak
Latar belakang: Sepsis neonatus salah satu sindrom klinis pada bayi yang berusia 28 hari atau lebih. Menurut data WHO pada 19 april 2018 di perkirakan 3 juta bayi baru lahir dan 1,2 juta anak menderita sepsis secara global setiap tahun. Penilaian profil hematologi dapat digunakan sebagai pedoman klinis untuk diagnosis sepsis dan tatalaksana awal pederita sepsis awitan dini terutama pada rumah sakit dengan fasilitas terbatas dan hasil pemeriksaan lebih cepat didapat.
\end{abstract}

Tujuan: Penelitian ini bertujuan untuk mengetahui gambaran profil hematologi pada pasien sepsis di unit neonatus di RSUD Dr. Pirngadi Medan.

Metode: Penelitian ini bersifat deskriptif dengan desain cross-sectional. Sampel penelitian dipilih dengan total sampling.

Hasil: Hasil penelitian didapati dari 74 neonatus, sebanyak 44 orang (59,5\%) berjenis kelamin laki-laki. Neonatus dengan persalinan normal sebanyak 57 orang $(78,1 \%)$ dan yang bertahan hidup sebanyak 45 orang $(60,8 \%)$. Ditemukan leukosit $(76,4 \%)$, neutrofil $(60 \%)$, monosit $(87,9 \%)$, dan hemoglobin $29(40,3 \%)$ meningkat. 
Kesimpulan: Profil hematologi dapat digunakan sebagai penilaian klinis sepsis dalan 24 jam pertama pada neonatus. Pemeriksaan hematologi didapati peningkatan pada leukosit, neutrofil, monosit, dan hemoglobin pada pasien sepsis neonatus dalam 24 jam pertama.

Kata Kunci: sepsis, neonatus, profil hematologi

\section{Pendahuluan}

Sepsis merupakan salah satu penyebab utama morbiditas dan mortalitas pada neonatus di seluruh dunia, terlepas dari kemajuan terbaru dalam sistem perawatan kesehatan. Sepsis neonatal salah satu sindrom klinis pada bayi yang berusia 28 hari atau lebih muda. Sepsis diawali dengan manifestasi tanda-tanda sistemik infeksi dan isolasi patogen bakteri dari aliran darah. ${ }^{1}$ Infeksi mungkin dapat terjadi di dalam kandungan melalui jalur transplasenta atau trans-servikal selama atau setelah persalinan. Infeksi asendens melalui serviks, dengan satupun tanpa ketuban pecah, dapat menyebabkan sepsis. Beberapa manifestasi klinis memperlihatkan inflamasi seperti demam atau hipotermia, takikardi, dan leukositosis atau leukopenia. ${ }^{2}$

Insiden sepsis bervariasi dengan gejala klinis tidak khas dan progresivitas gejala dapat terjadi dalam 24 jam. ${ }^{3}$ Adanya sepsis berat dan syok sepsis juga ditandai dengan disfungsi multiorgan dan apabila terjadi hipotensi tidak langsung memberikan respons terhadap resusitasi cairan yang adekuat maka akan menyebabkan syok septik. 2,4,5 Berdasarkan buletin yang diterbitkan oleh WHO (World Health Organization) pada 19 April 2018, diperkirakan tiga juta bayi baru lahir dan 1,2 juta anak menderita sepsis secara global setiap tahun. ${ }^{6}$ Insiden sepsis berkisar 1:1500 pada bayi cukup bulan dan 1:250 pada bayi yang kurang bulan. ${ }^{7}$ Angka kejadian sepsis pada bayi kurang bulan enam kali lebih berisiko dibandingkan bayi cukup bulan. Hal ini berhubungan dengan sistem imun yang imatur serta perawatan di rumah sakit yang berkepanjangan sehingga terjadi peningkatan risiko infeksi nosokomial. ${ }^{8}$ Sepsis dan syok septik berat merupan salah satu penyebab utama kematian di ICU yang meliputi 2-11\% dari kasus rawat inap di rumah sakit atau ICU di AS dan Eropa. ${ }^{2}$ Pada unit perawatan intensif Rumah Sakit Cipto Mangunkusumo (RSCM) Jakarta, 19,3\% dari 502 pasien anak yang dirawat yang mengalami sepsis dengan angka mortalitas 54\%. ${ }^{9}$ Profil kesehatan Provinsi Bangka Belitung melaporkan penyebab kematian neonatus paling banyak adalah BBLR $(43,22 \%$ dari total kematian neonatus), asfiksia (29,66\% dari total kematian neonatus), kelaian kongenital $(9,32 \%$ dari total kematian neonatus), lain-lain (16,94\% dari total kematian neonatus) dan sepsis $(0,84 \%$ dari total kematian neonatus). ${ }^{10}$ Di Sumatra Utara pada tahun 2008-2010 kejadian bayi diduga sepsis di unit perawatan neonatus RSUP. Adam Malik Medan adalah 239, di antaranya 158 terbukti sepsis, 103 dieksklusi (69 kelainan kongenital dan 34 data tidak lengkap). ${ }^{3}$

Salah satu pemeriksaan untuk mengetahui adanya infeksi adalah pemeriksaan kultur darah dan pemeriksaan ini bisa saja menjadi negatif palsu karena berbagai factor, salah satunya pemakaian antibiotik sebelumnya. ${ }^{11}$ Sistem skoring hematologi dapat digunakan sebagai pedoman klinis untuk diagnosis sepsis dan tatalaksana awal pederita sepsis awitan dini terutama pada rumah sakit dengan fasilitas terbatas dan hasil pemeriksaan lebih cepat didapat. ${ }^{12}$ Tahap awal infeksi yang terjadi pada sepsis ditandai dengan peningkatan jumlah neutrofil yang ditemukan pada darah perifer dan penurunan jumlah limfosit. ${ }^{13}$ Pada pasien sepsis dapat terjadi leukositosis maupun leukopenia. Leukositosis terjadi sebagai penanda adanya infeksi, inflamasi, trauma, stres fisik maupun mental. Leukopenia dapat terjadi karena kebutuhan terhadap leukosit meningkat, penurunan produksi sumsum tulang, infeksi virus, dan penurunan produksi limfoid. ${ }^{14,15}$

Peningkatan limfosit saat keadaan sepsis yang terus menerus akan menyebabkan terjadinya apoptosis dari limfosit sehingga limfositopenia. Penurunan eosinofil menjadi salah satu penanda infeksi pada sepsis dan terjadi peningkatan jumlah monosit karena monosit akan berinteraksi dengan endotoksin yang berasal dari bakteri. ${ }^{14,15}$ Perubahan trombosit juga terjadi pada sepsis akibat pelepasan faktor pertumbuhan pada sumsum tulang yang memacu produksi trombosit dalam ukuran besar sebagai mekanisme kompensasi.

Trombositopenia neonatus awitan dini terjadi pada $75 \%$ trombositopenia neonatus, pada umumnya telah ada saat lahir atau timbul dalam 72 jam pertama setelah lahir pada neoatus prematur atau yang lahir dari kehamilan yang mengalami komplikasi seperti insufisiensi plasenta dan hipoksia janin pada preeklampsia atau pertumbuhan janin terlambat. Trombositopenia neonatus awitan dini biasanya menunjukkan pola yang bisa diramalkan dan jumlah trombosit tidak menurun drastis atau sampai menimbulkan risiko pendaharan. Trombositopenia neonatus awitan lambat terjadi setelah 72 jam kehidupan hampir selalu disebabkan oleh sepsis awitan lambat atau enterokolitis nekrotikans (NEC). Trombositopenia telah ada seiring dengan ditemukan tanda-tanda awal sepsis atau NEC kemudian trombosit turun drastis dan mencapai titik terendah dalam waktu 24-48 jam. Penurunan trombosit dapat mencapai $50 \times 10^{9}$ dan sering membutuhkan transfusi trombosit. ${ }^{15,16}$ Pada penelitian didapati hasil sensitivitas dan spesifitas trombopoietin (TPO) tidak lebih tinggi dibandingkan dengan profil hematologi sebagai penanda diagnosis Sepsis Awitan Dini (SAD). ${ }^{16}$ Penelitian ini bertujuan untuk mengetahui gambaran angka kejadian sepsis, gambaran profil hematologi, dan gambaran karakteristik profil hematologi kejadian sepsis berdasarkan jenis kelamin, cara persalinan, dan luaran pada pasien sepsis di Unit Neonatus Rumah Sakit Umum Daerah Dr. Pirngadi Medan.

\section{Metode}

Penelitian ini merupakan penelitian deskriptif dengan desain crosssectional. Sampel pada penelitian ini berjumlah 74 sampel yang diambil dari data rekam medik seluruh penderita sepsis neonatus di RSUD Dr. Pirngadi Medan periode 01 Januari 2017 - Desember 2018 yang memenuhi kriteria inklusi dan eksklusi dan cara pemilihan sampel pada penelitan ini dengan total sampling. Kriteria inklusi pada penelitian adalah neonatus yang terkena sepsis setelah 24 jam terdiagnosis. Pasien sepsis yang memenuhi 2 kriteria dari SIRS (Systemic Inflamatory Response Syndrome) dengan frekuensi jantung yang abnormal, takipneu, suhu naik atau 
tidak, hitung jumlah leukosit abnormal dengan salah satu dari kedua kriteria tersebut harus terdapat suhu yang abnormal atau jumlah leukosit yang abnormal dan data rekam medik yang diagnosis akhir pasti sepsis neonatus dan data rekam medis yang lengkap, sedangkan kriteria eksklusi pada penelitian ini yaitu pasien sepsis neonatus yang lewat dari 24 jam dan pasien sepsis yang tercatat dalam rujukan.

\section{Hasil}

Pada tabel 1 dapat dilihat neonatus yang berjenis kelamin laki-laki sebanyak 44 orang $(59,5 \%)$ dan perempuan sebanyak 30 orang $(40,5 \%)$. Neonatus dengan persalinan normal yang terkena sepsis sebanyak 57 orang $(78,1 \%)$, sedangkan dengan persalinan seksio sesarea sebanyak 16 orang $(21,9 \%)$. Pasien sepsis neonatus yang pulang sehat terdiri dari 45 orang $(60,8 \%)$ dan yang meninggal sebanyak 29 pasien $(39,2 \%)$.

Tabel 1. Distribusi Jenis Kelamin, Persalinan, dan Luaran Pasien Sepsis Neonatus

\begin{tabular}{lcc}
\hline \multicolumn{1}{c}{ Kategori } & $\begin{array}{c}\text { Frekuensi } \\
\text { (orang) }\end{array}$ & $\begin{array}{c}\text { Persentase } \\
\text { (\%) }\end{array}$ \\
\hline $\begin{array}{l}\text { Jenis Kelamin, } \mathrm{n}(74) \\
\text { Laki-laki }\end{array}$ & 44 & 59,5 \\
$\quad$ Perempuan & 30 & 40,5 \\
Persalinan, $\mathrm{n}(73)$ & & \\
$\quad$ Normal & 57 & 78,1 \\
Seksio Sesaria & 16 & 21,9 \\
Luaran, n (74) & & \\
$\quad$ Survive/Bertahan Hidup & 45 & 60,8 \\
Meninggal & 29 & 39,2 \\
\hline
\end{tabular}

Pada tabel 2 dapat dilihat neonatus sepsis dengan nilai eritrosit normal sebanyak 38 orang $(52,8 \%)$, nilai eritrosit menurun sebanyak 25 orang $(34,7 \%)$, dan nilai eritrosit meningkat sebanyak 9 orang (12,5\%). Neonatus sepsis dengan nilai leukosit normal sebanyak 16 orang $(22,2 \%)$, nilai leukosit meningkat sebanyak 55 orang $(76,4 \%)$, dan nilai leukosit menurun sebanyak 1 orang $(1,4 \%)$. Neonatus sepsis dengan nilai neutrofil normal sebanyak 9 orang $(16,4 \%)$, nilai neutrofil meningkat sebanyak 33 orang $(60,0 \%)$, dan nilai neutrofil menurun sebanyak 13 orang $(23,6 \%)$. Neonatus sepsis dengan nilai eosinofil normal sebanyak 50 orang $(75,8 \%)$, nilai eosinofil meningkat sebanyak 16 orang $(24,2 \%)$. Neonatus sepsis dengan nilai basofil normal sebanyak 43 orang $(67,2 \%)$, nilai basofil meningkat sebanyak 21 orang $(32,8 \%)$. Neonatus sepsis dengan nilai monosit normal sebanyak 7 orang $(12,1 \%)$, nilai monosit meningkat sebanyak 51 orang $(87,9 \%)$. Neonatus sepsis dengan nilai limfosit normal sebanyak 38 orang $(65,5 \%)$, nilai limfosit meningkat sebanyak 20 orang $(34,3 \%)$. Neonatus sepsis dengan nilai trombosit normal sebanyak 42 orang $(59,2 \%)$, nilai trombosit meningkat sebanyak 9 orang $(12,7 \%)$, dan nilai trombosit menurun sebanyak 20 orang $(28,2 \%)$. Neonatus sepsis dengan nilai hemoglobin normal sebanyak 26 orang $(36,1 \%)$, nilai hemoglobin meningkat sebanyak 29 orang $(40,3 \%)$, dan nilai hemoglobin menurun sebanyak 17 orang $(23,6 \%)$.

\section{Kesimpulan}

Pada penelitian ini didapati hasil profil hematologi dalam 24 jam pertama setelah terdiagnosis yang didapat data dari rekam medis
Tabel 2. Distribusi Profil Hematologi Pasien Sepsis Neonatus

\begin{tabular}{lccc}
\hline Eritrosit & Kategori & Frekuensi & Persen \\
$\mathbf{n}(\mathbf{7 2})$ & $4-5.40 \times 10^{6} / \mathrm{ul}$ & 38 & 52,8 \\
Normal & $>5.40 \times 10^{6} / \mathrm{ul}$ & 9 & 12,5 \\
Meningkat & $<4 \times 10^{6} / \mathrm{ul}$ & 25 & 34,7 \\
Menurun & &
\end{tabular}

\section{Leukosit}

$\mathrm{n}(72)$

Normal

Meningkat

$4-11.0 \times 10^{3 / u}$

Menurun

$>11.0 \times 10^{3 /} / \mathrm{ul}$ $<4 \times 10^{3} / \mathrm{ul}$

22,2

Neutrofil

$\mathrm{n}(55)$

\begin{tabular}{lccc} 
& & \\
\hline Normal & $5-7 \times 10^{3} / \mathrm{ul}$ & 9 & 16,4 \\
Meningkat & $>7 \times 10^{3} / \mathrm{ul}$ & 33 & 60.0 \\
Menurun & $<5 \times 10^{3} / \mathrm{ul}$ & 13 & 23,6
\end{tabular}

Menurun $<5 \times 10^{3} / \mathrm{ul}$ 23,6

Eosinofil

$\mathrm{n}(60)$

\begin{tabular}{lccc}
\hline Normal & $0.00-0.50 \times 10^{3} / \mathrm{ul}$ & 50 & 75,8 \\
Meningkat & $>0.50 \times 10^{3} / \mathrm{ul}$ & 16 & 24,2 \\
\hline Basofil & &
\end{tabular}

$\mathrm{n}(64)$

$\begin{array}{llll}\text { Normal } & 0.0-0.10 \times 10^{3} / \mathrm{ul} & 43 & 67,2\end{array}$

\begin{tabular}{llll} 
Meningkat & $>0.10 \times 10^{3} / \mathrm{ul}$ & 21 & 32,8 \\
\hline
\end{tabular}

Monosit

$\mathrm{n}(58)$

\begin{tabular}{lccc}
\hline Normal & $0.10-0.80 \times 10^{3} / \mathrm{ul}$ & 7 & 12,1 \\
Meningkat & $>0.80 \times 10^{3} / \mathrm{ul}$ & 51 & 87,9
\end{tabular}

Limfosit

$\mathrm{n}(58)$

Normal $\quad 1.0-4.0 \times 10^{3} / \mathrm{ul} \quad 38 \quad 65,5$

\begin{tabular}{llll} 
Meningkat & $>4.0 \times 10^{3} / \mathrm{ul}$ & 38 & 65,5 \\
\hline
\end{tabular}

Trombosit

n (71)

\begin{tabular}{lccc}
\hline Normal & $150-400 \times 10^{3} / \mathrm{ul}$ & 42 & 59,2 \\
Meningkat & $>400 \times 10^{3} / \mathrm{ul}$ & 9 & 12,7 \\
Menurun & $<150 \times 10^{3} / \mathrm{ul}$ & 20 & 28,2 \\
\hline Hemoglobin & & & \\
$\mathbf{n}(72)$ & $12-16 \mathrm{~g} / \mathrm{dL}$ & 26 & 36,1 \\
\hline Normal & $>16 \mathrm{~g} / \mathrm{dL}$ & 29 & 40,3 \\
Meningkat & $<12 \mathrm{~g} / \mathrm{dL}$ & 17 & 23,6 \\
Menurun & & & \\
\hline
\end{tabular}

di mana umur $<28$ hari lebih rentan terkena sepsis neonatus seperti penelitian di Fakultas Kedokteran Universitas Islam Malang menyatakan tingkat mortalitas yang tinggi pada pasien sepsis neonatorum dengan usia $<28$ hari. ${ }^{14}$ Pada penelitian ini didapatkan neonatus sepsis lebih banyak berjenis kelamin laki-laki. Banyak penelitian yang menyimpulkan bahwa anak laki-laki lebih rentan, salah satunya pada penelitian Nur'izzati dkk/et.al menyimpulkan bahwa sepsis neonatorum lebih banyak terjadi pada anak laki-laki dibandingkan perempuan. ${ }^{15}$ Pada penelitian ini neonatus sepsis dengan persalinan normal lebih banyak dibandingkan neonatus dengan persalinan seksio sesarea, di mana persentase persalinan normal $78,1 \%$. Pasien sepsis neonatus yang meninggal dengan persetnase $39,2 \%$ dan yang sehat $60,8 \%$. Penelitian sebelumnnya menyatakan masih tingginya mobilitas dan mortalitas kejadian sepsis neonatus baik di negara maju maupun berkembang .1,3

Pada penelitian ini didapatakan neonatus sepsis dengan nilai eritrosit normal sebanyak 38 pasien $(52,8 \%)$. Pada penelitian sebelumya Adriani R dkk menemukan nilai batas abnormalitas pada eritrosit. ${ }^{12}$ Pada penelitian ini didapati peningkatan leukosit pada pasien sepsis yang terdiri dari 55 pasien (76,4\%). Penelitian Fitriani dkk menyimpulkan pada pasien usia $\leq 28$ hari yang hidup maupun yang meninggal mayoritas memiliki jumlah leukosit normal. ${ }^{14}$ Penelitian Wirawati dkk menyatakan adanya hubungan 
signitifikan kenaikan leukosit pada pasien sepsis neonatus. ${ }^{17}$ Penelitian lainnya yang dilakukan Nur'izzati dkk pada pasien sepsis dapat terjadi leukositosis maupun leukopenia. Leukositosis terjadi sebagai penanda adanya infeksi ataupun inflamasi sedangkan leukopenia dapat terjadi pada pasien sepsis karena kebutuhan terhadap leukosit meningkat, penurunan produksi sumsum tulang, infeksi virus dan penurunan produksi limfoid. ${ }^{15}$ Pada konsensus diagnosis dan tatalaksana sepsis pada anak, penanda infeksi pada anak sepsis leukosit pada umur 0 har sampai 1 minggu: $>34.000 \mathrm{~mm}^{3} .9$

Nilai neutrofil meningkat terjadi pada 33 pasien $(60,0 \%)$. Hal ini serupa dengan penelitian di Fakultas Kedokteran Universitas Islam Malang yang menyatakan menurunnya jumlah dan menurunnya fungsi neutrofil sehingga akan menyebabkan keadaan immunocompromised. Keadaan neutropenia pada sepsis neonatus menyebabkan prognosis yang buruk. ${ }^{14}$ Nilai eosinofil pada pasien ini didapatkan normal pada 50 pasien $(75,8 \%)$. Penelitian Nur'izzati dkk menemukan nilai eosinofil menjadi salah satu penanda infeksi pada sepsis. ${ }^{14,15}$ Nilai basofil normal didapatkan pada 43 pasien $(67,2 \%)$ pada penelitian ini. Pada penelitian sebelumnya ditemukan peningkatan nilai sel neutrofil pada pasien sepsis bakteri sehingga banyak pasien mengalami neutrofillia. Nilai eosinofil pada pasien sepsis bakteri banyak mengalami penurunan sehingga terjadi eosinopenia sedangkan untuk nilai basofil pada pasien sepsis bakteri tidak mengalami penurunan maupun peningkatan yang signifikan. ${ }^{18}$

Pada penelitian ini didapat nilai monosit meningkat pada 51 pasien (87,9\%\%). Pada penelitian Nur'izzati dkk didapatkan terjadi peningkatan jumlah monosit pada pasien sepsis karena monosit akan berinteraksi dengan endotoksin yang berasal dari bakteri. ${ }^{14,15}$ Nilai limfosit normal pada dari 38 pasien $(65,5 \%)$ dan pasien yang mengalami limfositosis sebanyak $34,5 \%$. Penelitian sebelumnnya menyatakan pada pasien sepsis dapat terjadi penurunan limfosit dan pada keadaan awal sepsis dapat terjadi peningkatan limfosit di mana keadaan sepsis yang terus-menerus akan menyebabkan terjadinya apoptosis dari limfosit sehingga limfositopenia. ${ }^{14,15}$ Pada konsensus diagnosis dan tatalaksana sepsis pada anak penanda infeksi pada anak limfopenia menunjukkan diagnosis bakteremia $<13.000 / \mu .^{9}$

Nilai trombosit normal terjadi pada $59,2 \%$ pasien. Pada penelitian sebelumnya yang di lakukan Wilar dkk menyimpulkan bahwa tidak ada hubungan antara penurunan trombosit dengan kejadian sepsis neonatorum. ${ }^{16}$ Penelitian oleh Roeslani dkk menyatakan bahwa pemeriksaan darah perifer lengkap (hemoglobin, leukosit, trombosit, hematokrit) dalam batas normal. ${ }^{19}$ Penelitian Nur'izzati dkk menyatakan adanya penurunan trombosit pada pasien sepsis neonatoum. Terjadinya penurunan jumlah trombosit disebabkan oleh peningkatan destruksi trombosit, sekuestrasi sekunder terhadap infeksi, serta kegagalan produksi trombosit akibat penurunan jumlah megakariosit atau efek perusakan oleh endotoksin. ${ }^{15}$ Beberapa penelitian sebelumnya juga mengatakan trombositopenia pada pasien sepsis jumlah nilai trombosit tidak menurun drastis atau sampai menimbulkan pendarahan dan titik terendah trombosit turun pada pasien sepsis terjadi biasanya dalam waktu 48 jam sehingga dibutuhkan transfusi trombosit. ${ }^{14,15}$
Nilai hemoglobin yang mengalami peningkatan terjadi pada 40,3\% pasien. Penelitian Roeslani dkk menyimpulkan bahwa pemeriksaan darah perifier (hemoglobin, trombosit, leukosit, hemtokrit) pada pasien sepsis dalam batas normal. ${ }^{19}$

Kelemahan pada penelitian ini adalah data rekam medis yang tidak lengkap yang menyebabkan jumlah sampel untuk setiap variabel menjadi berbeda.

\section{Kesimpulan}

Profil hematologi dapat digunakan sebagai penilaian klinis sepsis dalam 24 jam pertama pada neonatus. Pemeriksaan hematologi didapati peningkatan pada leukosit, neutrofil, monosit, dan hemoglobin pada pasien sepsis neonatus dalam 24 jam pertama.

\section{Ucapan Terima Kasih}

Peneliti mengucapkan banyak terimakasih kepada Universitas HKBP Nommensen dan pihak rekam medis RSUD Dr.Pirngadi yang telah memberikan kesempatan kepada peneliti untuk melakukan dan menyelesaikan penelitian ini.

\section{Daftar Pustaka}

1. Sorsa A. Epidemiology of Neonatal Sepsis and Associated Factors Implicated: Observational Study at Neonatal Intensive Care Unit of Arsi University Teaching and Referral Hospital, South East Ethiopia. NCBI. 2019;29(3):333.

2. Mandal B., Wilkins EG., Dunbaar E., Mayon-White RT. Lecture Notes Penyakit Infeksi. 6th ed. Safitri A, editor. Jakarta: Erlangga; 2008. 9-10 p.

3. Sianturi $P$, Hasibuan BS, Lubis BM, Azlin E, Tjipta GD. Profil sepsis neonatus di unit perawatan neonatus Adam Malik. Sari Pediatr. 2012;14(2):67-72.

4. Singer M, Deutschman CS, Seymour CW, Shankar-Hari M, Annane D, Bauer $\mathrm{M}$, et al. The third international consensus definitions for sepsis and septic shock. HHS Public Access. 2016;315(8):801-10.

5. Liu X, Shen $Y$, Wang $H, G e Q$, Fei A, Pan S. Prognostic significance of neutrophil-to-lymphocyte ratio in patients with sepsis: a prospective observational study. Mediators Inflamm. 2016.

6. World Health Organization. Neonatal Mortality [Internet].2019. Available from: https://www.who.int/gho/child_health/mortality/neonatal_text/en/

7. World Health Organization. Sepsis [Internet]. 2018. Available from: https://www.who.int/news-room/fact-sheets/detail/sepsis

8. Marcdante KJ, Kliegman RM, Jenson HB, Behrman RE. Nelson IImu Kesehatan Anak Essensial. 6th ed. Suryawan A, Chairulfatah A, Pulungan $A B$, Endaryanto A, Pudjiadi A, Kurniawan A, et al., editors. Singapore: Elsevier; 2014. 284-286 p.

9. Mulya Rahma Karyanti. Pitfalls of Laboratory Interpretation for Infection. In: Trihono PP, Djer MM, Hendarto A, Prawitasari T, editors. Pitfalls in Pediatric Practices. Jakarta: Ikatan Dokter Anak Indonesia; 2012. p. 1-29.

10. Profil Kesehatan Provinsi Kepulauan Bangka Belitung. Depkes. 2017.

11. Jager CP de, Wijk PT van, Jongh-Leuvenink RBMJ de, Poll T van der, Peter C Wever. Lymphocytopenia and neutrophil-lymphocyte count ratio predict bacteremia better than conventional infection markers in an emergency care uni. Crit Care. 2010.

12. Adriani R, Yantri E, Mariko R. Peran sistem skoring hematologi dalam diagnosis awal sepsis neonatorum awitan dini. Sari Pediatr. 2018;20(1):1723.

13. Holub M, Beran O, Kaspríková N, Chalupa P. Neutrophil to lymphocyte count ratio as a biomarker of bacterial infections. Cent Eur J Med.2012;258261

14. Fitriani EC, Amalia Y, Diah Andriana. Hubungan kadar dan hitung jenis leukosit pada angka mortalitas neonatus dan bayi akibat sepsis di Kabupaten Malang. Jurnal Bio Komplementer Medicine. 2019;6(3):183-9. 
15. Nur'izzati, Maani H, Husni. Gambaran hematologic scoring system pada tersangka sepsis neonatorum. J Kesehat Andalas. 2018;7(3):1-5.

16. Wilar R, Antolis $Y$, N.N.Tatura S, Gunawan S. Jumlah trombosit dan mean platelet volume sebagai faktor prognosis pada sepsis neonatorum. Sari Pediatr. 2010;12(1):53-7.

17. Putri IA, Aryati, Lestari AAW. Peranaan immature/total (i/t) ratio, jumlah leukosit dan procalcitonin (pct) dalam menegakkan diagnosis sepsis. Airlangga; 2016.
18. Arumaningsih F, Suhariyadi. Hubungan nilai sel polimorfonuklear (neutrofil,eosinofil,dan basofil) dengan kadar procalcitonin pada pasien sepsis bakteri. Anal Kesehat Sains. 2018;7(2):609-17.

19. Roeslani RD, Amir I, Nasrulloh MH, Suryani. Penelitian awal faktor risiko sepsis neonatorum awitan dini. Sari Pediatr. 2013;14(6):363-8. 